\title{
Reporting the implicit pension debt in low- and middle-income countries
}

Received (in revised form): 26th March, 2001

\section{Robert Holzmann,*}

is the Director of the Social Protection Department of the World Bank. Until 1997 he was professor of economics at the Universities of Saarland (Germany) and Vienna (Austria) and guest professor at universities in Chile, Japan and the USA. As principal administrator at the OECD (1985-87), he wrote a comprehensive report on public pension reform in industrialised countries. At the IMF (1988-1990), he was working on fiscal and social security issues of Central and Eastern Eruopean transition economies, and he researched intensively the economic and financial market effects of the Chilean pension reform.

\section{Robert Palacios}

is senior pension economist at the World Bank, contributed to the 1994 World Bank Publication on 'Averting the Old Age crisis' and is involved in many pension reforms worldwide.

\section{Asta Zviniene}

is social protection specialist at the World Bank and was educated in Lithuania and the USA.

*Robert Holzmann World Bank, $1818 \mathrm{H}$ Street, NW, Washington. Washington DC, 20433, USA

Tel: +1 202473 0931; Fax: +1202 522 3252; E-mail: rholzman@worldbank. org

\begin{abstract}
This paper argues that it is important to take into account unfunded public pension liabilities as part of an assessment of the overall fiscal situation. It examines the concept of the implicit pension debt (IPD) and presents estimates for 24 developing countries based on a consistent methodology and assumptions. The policy conclusions stress the need for standardised international reporting of this indicator.
\end{abstract}

Keywords: unfunded public pension liabilities; implicit pension debt (IPD); developing countries; standardising international reporting; policy conclusions

\section{Introduction}

Many public pension schemes that were installed or expanded in the post-war period are now maturing. The vast majority are unfunded, that is, pension obligations exist but there are no assets set aside to pay them. The present value of these promises is a liability not reported in standard fiscal accounts. It places important constraints on fiscal policy by committing a future stream of revenues to pay off this implicit pension debt (IPD). As discussed below, the magnitudes involved can be very large so it is not surprising that economists and policymakers are interested in grasping the size and nature of this liability.

Most of the work to date has focused on the IPD of richer, older countries. Yet, almost every developing country has at least one mandatory pension scheme that is not fully funded. Among some countries, such as the former socialist bloc in Central and Eastern Europe, the pension debts relative to national income are extremely large and have serious implications for the intertemporal budget constraint. Others are accumulating IPD at a rapid and probably unsustainable rate. In fact, the situation even in young developing countries is alarming when 
weak tax collection is taken into account; IPD relative to the tax base, like external debt service to export ratios, may be a better indicator of sustainability. Regardless of the indicator used, this paper argues that it is important to assess the scope of IPD in developing countries as part of the overall fiscal policy discussion.

Growing interest in IPD reflects three interrelated developments. First, in a globalising world, governments are increasingly worried about the intertemporal balance (or lack thereof) of their fiscal accounts. With globalisation, governments are not easily able to enforce high tax rates on their economies. At the same time, default on domestic debt through inflation is still possible but increasingly expensive as financial markets screen for fiscal sustainability and penalise unsound fiscal policy much earlier than in the past.

Secondly, many countries have started to reform their pension systems, and many of these reforms involve a shift from an unfunded, defined benefit scheme to a multi-pillar scheme with a component that is fully funded. In this process, unfunded liabilities often become explicit and governments want to know their size before launching such a reform.

Finally, if part of the motivation for pension reform is fiscal sustainability, a summary indicator is needed to see if the reform actually improves the government's balance sheet. While Generational Accounting provides such a measure, it involves too many other programmes, many of which are not as readily subjected to an intertemporal allocation of costs and benefits. To this end, the estimated IPD plus the change in the conventionally defined debt that is generated by a pension reform provides a provides a better performance indicator.

Different definitions, assumptions, and methodologies confuse the discussion of pension liabilities. For example, the actuarial deficit of a pension scheme and the accrued-to-date liability involve different concepts. Different assumptions are used for discounting or indexing pensions across studies. Last but not least, estimations entail the use of different models that render comparisons between countries problematic. This paper attempts to overcome these comparability issues.

The next section stresses the importance of IPD in the context of public finance. The third section clarifies concepts relating to IPD, while the fourth section presents estimates based on identical assumptions for a diverse sample of 23 countries using the World Bank's 'Pension Reform Options Simulation Toolkit' (PROST) computer model. The final section concludes and stresses the need for standardised international reporting of the IPD indicator. The Appendix presents the methodological underpinnings of the estimations the country assumptions and detailed results.

\section{The relevance of IPD estimates in fiscal policy}

Recently the concept of implicit pension debt has penetrated the public discussion in many countries on the basic premise that it shares some important features with the explicit, conventionally defined public debt, and therefore needs to be taken into account in a macroeconomic analysis that includes an assessment of fiscal sustainability. ${ }^{1}$ This section sketches out the similarities and differences between implicit and explicit debt, the importance of good estimates of IPD, and the reasons why Generational Accounting cannot substitute for IPD estimates. 


\section{Similarities and differences between implicit and explicit public debt}

When establishing an unfunded (pay-as-you-go) pension scheme, mandating the payment of contributions to the current generation and promising to pay future pension benefits, the government makes commitment. Since in essentially all cases the schemes do not set aside initial contributions to pay future benefits but use them to pay windfall benefits to the current older generations that contributed little, mature public pension schemes are typically unfunded. ${ }^{2}$ While there are quite a few partially funded schemes, most have assets that cover only a small fraction of liabilities. In contrast to private sector pension schemes in some countries (for example, the Netherlands and the USA), there are essentially no examples of fully funded, publicly run, defined benefit schemes. ${ }^{3}$ Taking money (contributions) now with the promise to repay (benefits) in the future, out of future contributions (taxes) makes the underlying debt akin to government borrowing. However, there are differences that must be kept in mind.

While many economists compare making unfunded pension promises to issuing government bonds, ${ }^{4}$ several economists hold that this analogy has its limitations (for example, Rizzo, 1990). Perhaps most importantly, the creditors in a pay-as-you-go (PAYG) pension scheme do not enter into the agreement voluntarily, but rather are forced by law to participate. A related difference is the fact that there is no market for trading these promises, whereas individuals can sell (and borrow against) their government bonds with relative ease. Furthermore, the return on the government bond is known (at least the nominal yield), while the ultimate value of a PAYG pension promise depends on a wide array of variables entering the defined benefit formula as well as the possibility that the government may change the formula itself in response to other fiscal demands. Last but not least, the compulsory nature of the pay-as-you-go pension arrangement implies that there is some tax element in mature schemes, usually through an implicit rate of return below the market rate of interest. However, some of these characteristics can also be ascribed to government bonds in suppressed financial markets.

Governments generally have discretion to change the pension formula and thereby partially default on their liabilities. While this could create a distinction between government bonds and pension promises, this is a matter of degree; it may be easier to default on pension promises than bonds, but neither is without cost. On the one hand, it is highly unrealistic to assume that the pension obligations can be avoided altogether. There are few recorded cases of complete default on pension liabilities even in extreme cases. ${ }^{5}$ Rather, the argument holds that usually the government finds it easier to reduce its pension liability than to default or restructure its official public debt. Indeed, the frequent number of cost saving revisions to defined benefit formulas in public schemes over the last few decades seems to confirm this assertion. ${ }^{6}$ On the other hand, it is well known that governments can also default on explicit government debt fully or partially through the repudiation of the principal, reduction of interests due, inflation tax, or changes in taxation of interests due.

The true extent to which pension promises are more 'flexible' will depend on an assessment of the ability of the government to reduce benefits, which in turn, will depend on the political and social environment. The public's 
perception of their 'entitlement' to the payments, the ease with which they can observe the changes to often-complex benefit formulas, and the average age of the population are among the factors that are likely to determine how much room a government has to manoeuvre. ${ }^{7}$ In some cases, the courts may even use a broad interpretation of what is protected by the Constitution with implications for the ability of the governments to change the rules. Intervention by the courts to restrict changes that would have reduced the value of pension liabilities has already occurred in Argentina, Brazil, Croatia, and Poland. Unfortunately, there is little research in this area to date. ${ }^{8}$

\section{Reasons why good estimates of IPD are needed}

While some differences between implicit and explicit debt do exist, for many purposes they can be classified as public debt. Hence, knowledge about the scope and development of IPD is important for macroeconomic analysis and policy. In addition, good estimates of IPD are important for pension reform, ex-ante for its initiation and preparation, and ex-post for its assessment.

\section{Macroeconomic analysis and policy}

There are three main reasons why good estimates are needed for macroeconomic analysis and policy development. First, if unfunded pension commitments are public sector liabilities, the question emerges as to how they influence individual decisions of consumption and portfolio allocation. There is a large body of economic literature on macroeconomic implications of public pension systems that assumes that the acquisition of pension wealth through a pay-as-you-go plan may induce individuals to increase their lifetime consumption or lead them to try to compensate future generations that will have to pay off these obligations. ${ }^{9}$ In either case, economists treat these unreported obligations as determinants of observed behaviour. Unless there is pension debt on the government's balance sheet as a liability, pension wealth cannot exist on the individual's balance sheet as an asset. ${ }^{10}$ Furthermore, since pension assets and financial assets have different rates of return and these are imperfectly correlated, the size, rate of return, and volatility of pension wealth impact the portfolio composition of individuals. Secondly, since unfunded pension obligations are public debt, they co-determine the intertemporal budget constraint of government. Keeping the government solvent requires future tax revenue, partial default on its pension commitments, or future lower public expenditure elsewhere. Rising IPD accentuates these needs, and making good decisions about revenue and expenditure policy requires information about the current and future scope of the IPD. Thirdly, a given path of IPD with constant policy parameters reduces the ability of government to service the explicit pension debt and heightens the risk of default or monetary bail-out (Hochreiter, Winckler, and Brandner, 1998). Financial markets are increasingly aware of this link and compensate with a risk premium on government debt. Uncertainty about the true scope of IPD in the context of globalisation and mobile capital may increase this premium. Again, credible estimates should prove advantageous.

Initiating pension reform

When reforming a pension system, estimates about the initial and reform-induced changes in IPD are important. Estimates about the IPD and its future path under an unreformed 
system serve to inform the public about the need for reform. Estimates about the expected changes of the new IPD path serve to demonstrate the extent to which the reform will improve the long-run sustainability of the scheme. Mere concentration on the expenditure and revenue paths of the old and new systems does not provide the same information (although these projections are also crucial to inform the debate). This is because the reform may dramatically reduce the implicit debt, but the effects on expenditure and revenue paths occur only gradually. For example, changing from wage to price indexation (with a real wage growth of 2 per cent) has only modest initial effects on the fiscal balance of the scheme. Yet, as measured by the IPD, almost half of the reduction (some $1 / 6$ or 30 per cent of GDP in a typical mature OECD type pension scheme) takes place when this measure is implemented (Holzmann, 1998).

Equally important are estimates of IPD for a reform in which a shift to full or partial funding is envisaged. Such a move makes the implicit debt explicit. In many cases, the implicit debt is so large that the option of immediate conversion to funding is considered too disruptive to the fiscal accounts. The speed of the transition depends on how quickly traded government bonds can replace implicit debt and what indirect costs this might place on the government. This in turn depends on initial conditions with respect to conventional debt, including its size and risk premium at the moment of transition. How much explicit debt can be allowed to emerge and in what sequence have a strong bearing on the reform design?

\section{Assessing pension reform}

When moving from unfunded to funded pensions, the full budgetary financing of an emerging transition deficit may not be feasible, and a partial debt financing can be justified based on tax-smoothing, consumption smoothing, and inter-generational considerations (Holzmann, 1998). Hence, while the reform reduces the implicit debt, this is partly compensated by an increase in the explicit debt. In order to assess the financial success of a pension reform and make sure that it actually leads to a fall in the overall government obligations, joint and rolling estimates of the IPD and the reform-induced explicit financial debt are required. ${ }^{11}$

\section{Generational accounts and pension reform}

Generational Accounting (GA) has become an important instrument for assessing the financial sustainability of the public sector. Estimates already exist for most industrialised countries and an increasing number of developing countries (Kotlikoff and Raffelhueschen, 1999; Auerbach, Kotlikoff, and Leibfritz, 1999) and are often added to more traditional budget presentations. A main indicator based on these estimates is the age profile of net-transfer age profile, ie, lifetime transfers minus taxes for each age cohort. By taking into account the changing demographic structure, the initial explicit debt, and public consumption expenditures, it highlights changes in the overall net burden on different generations. The impact of pension reform would be reflected in changes to the net-transfer profile by age cohort.

Aside from methodological problems that may affect GA estimates, ${ }^{12}$ their application for the assessment of pension reform is subject to certain limitations due to the nature of the exercise. First, since GA is applied to a broad set of programmes the methodology does not 
tend to consider the details of particular pension schemes. While this could be remedied through more detailed analysis of this one programme, a more fundamental problem lies in the distinction made earlier in this paper. Contributory pension schemes are, more than other government expenditures, similar to repayment of loans. Aside from the potential indirect impact on growth, payments into and out of these systems can be assigned to specific generations in a way that general revenue-financed programmes like social assistance cannot. This, in fact, is the argument for changing the accounting of pension liabilities in the first place as has been pointed out by some of the major proponents of GA (Kotlikoff, 1986).

Another problem with GA for assessing pension reform outcomes is that by definition it relies on projections of revenues for the calculation of the net transfer by age. This requires more heroic assumptions, especially in developing countries with partial coverage of the labour force. For example, most public pension schemes currently cover less than half of the labour force, but international patterns and the historical experience of developed countries suggest that coverage expands as incomes rise. As a result, the outcome for a particular generation based on a GA analysis of the pension system depends heavily on the assumed path of coverage. The longer the 'Ponzi scheme' can be kept going by adding new contributors, the more positive the net transfer to current generations. As discussed below, this is similar to the problems found in the net pension liability calculation and is one of the reasons that we choose to focus on gross IPD.

Finally, it should be pointed out that, just as different definitions of the pension liability provide different insights over time and across countries, GA can complement IPD measures and can even be applied specifically to the pension system in isolation in a useful way. ${ }^{13}$

\section{Alternative definitions of the Implicit Pension Debt}

While the concept of IPD appears intuitively simple and straightforward, in reality there are different definitions of IPD and methods for calculating it. This section starts out by highlighting the different types of unfunded pension liabilities, including those of privately managed schemes. Next, it presents alternative definitions of the scope of IPD for the typical defined benefit schemes. Since there is no single accepted methodology for calculating the liability of public, unfunded, defined benefit schemes, the second subsection reviews the experience in the private sector. The final subsection reviews existing estimates for pubic sector liabilities. This sets the stage for the proposed pragmatic methodology for international comparisons in the fourth section of the paper.

\section{Different types of unfunded pension liabilities}

The last section focused on the unfunded, defined benefit-type public pension promise, which is the most common in the world today. ${ }^{13}$ But there is a variant of this promise emerging the notional defined contribution scheme (NDC) - and there are at least two other types of public pension promises that imply liabilities for the government and that are linked with privately provided voluntary and mandatory schemes. Table 1 lists the types of pension liability and examples of countries where they are relevant, and the text briefly discusses their main characteristics in turn. 
Table 1: Types of unfunded public pension liabilities

\section{Source of liability}

Guarantees for voluntary private schemes

Guarantees for mandatory private schemes

Unfunded, public defined benefit schemes

Unfunded, public notional account schemes

\section{Examples of countries where operative}

United States

Chile, Mexico, United Kingdom and Hungary

Most countries with varing degrees of coverage Italy, Latvia, Poland and Sweden
Guarantees of privately managed defined-benefit plans take many different forms. In the USA, employer-sponsored defined benefit plans pay the Pension Benefit Guarantee Corporation (PBGC) a premium, which serves to insure some portion of the acquired pension rights of covered workers if funding levels are not sufficient to cover liabilities at termination. This guarantee does not extend, however, to indexation of benefits, making workers who depend on it highly susceptible to inflation risk.

In the UK and Japan, the government explicitly provides a guarantee against inflation that protects workers who have opted to 'contract-out' of the public scheme and enter an employer-sponsored defined benefit plan. In the UK, this guarantee is triggered at inflation levels above 5 per cent, while the Japanese government pays the entire cost of inflation indexation for the more than $8 \mathrm{~m}$ workers who have contracted out through their employer pension funds. The nature of government guarantees of defined benefit schemes in the private sector vary across countries and are not always explicit. The size of the contingent liabilities associated with them depends on the funding rules and private pension coverage. Coverage ranges from practically nil in many developing countries to very high in countries such as the Netherlands and Switzerland.

Minimum pension guarantees of publicly mandated, privately managed defined contribution schemes were until recently found only in Chile, where they were designed to serve as the redistributive element and social safety net for the new system of privately managed pension firms known as Administradoras de Fondos de Pensiones or AFPs. The minimum pension guarantee requires that the government pay an amount equivalent to the difference between the accumulated balance in an individual worker's private pension account at time of retirement and the amount that would provide an annuity equivalent to a pre-specified minimum pension. In recent years, this minimum has hovered around 25 per cent of the average wage in Chile for workers who fulfill the required 20-year vesting requirement. ${ }^{15}$

The Colombian scheme offers a minimum pension guarantee in its new privately managed tier that is quite high relative to the average covered wage. The magnitude of the contingent liability associated with this type of minimum pension guarantee will be a function of several factors, including the real rate of return achieved by the new private pension funds, the size distribution of covered wages, labour force participation and unemployment, evasion, and changes in life expectancy that affect the annuity.

The new Mexican pension system has incorporated a complex hybrid guarantee. It allows members of the scheme at the time of the reform to take the PAYG pension they would have received under the pre-reform PAYG scheme if it is higher than what they are able to generate in the new funded scheme. Hungary has a similar guarantee for those with at least 15 years of contributions to the privately managed pension system. In 
the Hungarian case, the guarantee is specified as a fraction of the residual PAYG pension. This means that in both countries the liability will depend on the same factors associated with the minimum pension guarantees, but also on other factors that determine the benefits in their respective PAYG schemes.

Finally, several countries including Chile, Poland and Argentina guarantee relative rates of return on defined contribution accounts. In the event that a particular pension fund performs substantially below the average for the other pension funds over a certain period of time (say, 24 months as in the case of Chile), the private provider and ultimately the government is required to make up part of the difference.

Unfunded liabilities of publicly managed defined benefit plans refer to those liabilities arising from 'social insurance' schemes that currently dominate public pension provision around the world. These schemes have proliferated since they first appeared over a century ago and are now found in more than 150 countries. They cover the vast majority of the labour force and the elderly in the industrial world. Global labour force coverage of public pension schemes has been estimated at around 40 per cent, and most covered workers participate in schemes of this type. Many countries have multiple schemes that cover specific groups of workers, most commonly the military and civil servants, and many of these are non-contributory. The liability in the case of unfunded social insurance type pension promises are very large, as discussed below.

Unfunded liabilities of publicly managed defined contribution plans have emerged in the last few years. The 'notional defined contribution' pension combines the individual accounts of a privately managed defined contribution scheme with PAYG financing. This results in an individual worker with a government promise whose value should be almost as easy to monitor at any given point in time as a government bond. ${ }^{16}$ The individual account balance is increased by a specified rate of return determined by the government, and the notional accumulation is divided by life expectancy to calculate the annual payment upon retirement. This rate of return has been set at the rate of growth of the covered wage bill or average wages, and in the case of Italy to the rate of GDP growth. The purpose of tying it to these indicators is to link the growth of liabilities to the growth of projected revenues in some way. However, this does not guarantee sustainability. The choice of the notional interest rate as well as other design features, such as minimum benefits and indexation of the calculated annuity, have a bearing on the fiscal sustainability and therefore on the government liability in view of economic and demographic shocks (Disney, 1999; Palmer, 2000; Valdes-Prieto, 2000).

This arrangement may reinforce the analogy with bonds in the minds of the public and may make the liability easier to measure and observe. To the extent that this reduces perceived risk associated with the pension promise, it could increase the credibility of the scheme. On the other hand, if the difference between the average rates of return in the scheme and in the market remains and evasion is relatively easy, it may have the opposite impact. At the same time, some flexibility to reduce the obligations may be lost.

As a final note, other types of pension promises not included in Table 1 are the universal or basic pensions that are provided on the basis of citizenship in New Zealand, Canada, Mauritius, and the Nordic countries, and the 
Table 2: Alternative definitions of pension liabilities, actuarial deficits, and their interaction

\begin{tabular}{|c|c|c|c|}
\hline Assets & Liabilities & Definition of balance & Definition of liability \\
\hline Financial reserves & $\begin{array}{l}\text { Present value of } \\
\text { pensions in } \\
\text { disbursement }\end{array}$ & & \\
\hline Actuarial Deficit I & $\begin{array}{l}\text { Present value of future } \\
\text { pensions due to past } \\
\text { contributions of } \\
\text { current workers }\end{array}$ & & \\
\hline $\begin{array}{l}\text { Gross implicit pension } \\
\text { debt I }\end{array}$ & $\begin{array}{l}\text { Gross implicit pension } \\
\text { debt I }\end{array}$ & \multirow{3}{*}{$\begin{array}{l}\text { Actuarial Deficit I = } \\
\text { net-implicit pension } \\
\text { debt I }\end{array}$} & \multirow[t]{3}{*}{ Accured to date liability } \\
\hline $\begin{array}{l}\text { Present value of future } \\
\text { contributions of } \\
\text { current workers }\end{array}$ & $\begin{array}{l}\text { Present value of future } \\
\text { pensions due to future } \\
\text { contributions of } \\
\text { current workers }\end{array}$ & & \\
\hline Actuarial Deficit II & & & \\
\hline $\begin{array}{l}\text { Gross implicit pension } \\
\text { debt II }\end{array}$ & $\begin{array}{l}\text { Gross implicit pension } \\
\text { debt II }\end{array}$ & \multirow{4}{*}{$\begin{array}{l}\text { Actuarial Deficit I+II= } \\
\text { net-implicit pension } \\
\text { debt II }\end{array}$} & \multirow[t]{4}{*}{$\begin{array}{l}\text { Projected current workers } \\
\text { and pensioner's liability }\end{array}$} \\
\hline $\begin{array}{l}\text { Gross implicit pension } \\
\text { debt of current } \\
\text { generation }\end{array}$ & $\begin{array}{l}\text { Gross implicit pension } \\
\text { debt of current } \\
\text { generation }\end{array}$ & & \\
\hline $\begin{array}{l}\text { Present value of } \\
\text { contributions of future } \\
\text { generations }\end{array}$ & $\begin{array}{l}\text { Present value of } \\
\text { pensions due to } \\
\text { contributions of future } \\
\text { generations }\end{array}$ & & \\
\hline $\begin{array}{l}\text { Actuarial Deficit III } \\
\text { Gross implicit pension } \\
\text { debt of future } \\
\text { generations }\end{array}$ & $\begin{array}{l}\text { Gross implicit pension } \\
\text { debt of future } \\
\text { generation }\end{array}$ & & \\
\hline $\begin{array}{l}\text { Gross implicit pension } \\
\text { debt of all generations }\end{array}$ & $\begin{array}{l}\text { Gross implicit pension } \\
\text { debt of all generations }\end{array}$ & $\begin{array}{l}\text { Actuarial Deficit I+II+III= } \\
\text { total actuarial deficit ie, } \\
\text { total net-IPD }\end{array}$ & Open system liability \\
\hline
\end{tabular}

means-tested pensions in Australia. An argument for reporting these liabilities based on the likelihood of having to keep these promises to future retirees could be made. New Zealand has opted not to report such liabilities at the moment, despite having moved to an accrual-based accounting scheme but does require periodic assessments of future costs. ${ }^{17}$

\section{Defining the scope of pension liabilities - alternative definitions}

This subsection reviews alternative definitions for pension liabilities of unfunded, defined benefit schemes and their link with the actuarial deficit of a pension scheme, another concept used in the pension policy discussion. There are three main definitions of pension liabilities, that is, the stock of commitments to pension future outlays (Franco, 1995). ${ }^{18}$

Accrued-to-date liabilities represent the present value of pensions to be paid in the future on the basis of accrued rights; neither future contributions, nor the accrual of new rights on the basis of these contributions are considered.

Projected liabilities of current workers and pensioners involve the assumption that pension schemes continue their existence until the last contributor dies, while no new entrants are allowed; both the future contribution of existing members and their new rights are therefore allowed under current rules. This is also referred to as the closed-group method for calculating these liabilities. 
Open-system liabilities include the present value of contributions and pensions of new workers under current rules; the range of options extends from including only children not yet in the labour force, to an infinite perspective. Normally, an arbitrary time period is chosen and the methodology is applied over that period.

Table 2 highlights the interrelation between the alternative definitions of pension liabilities and the concept of actuarial deficit, the balancing item. The difference between the three main definitions of pension liabilities (gross IPD) reflects alternative views of which generations, and their claims, should be considered. The difference between the gross and net concept results from taking account of assets (financial reserves and present value of future contributions); the net concept is equivalent to the balancing item, the actuarial deficit. The concept of debt or wealth represents alternative views from the side of government (debt) or individuals (wealth). For example, the gross IPD of the current generation (as seen from government) corresponds to the gross social security wealth (as seen from the individuals); and the net social security wealth corresponds to the actuarial deficit of the current generation. The concept of net/gross social security wealth was introduced into the pension discussion by Feldstein (1974). ${ }^{19}$

The appropriate definition for estimating the IPD depends on the economic policy question to be answered. To investigate the inter-temporal budget constraint, including the financial sustainability of a pension scheme, definition 3 appears to be the most appropriate. To investigate a move from unfunded to funded provisions, it is the first definition that is relevant, since it is the value of accrued rights that may have to be liquidated and, to the extent that this is financed through higher deficits, become explicit debt. For a given pension system, the main economic assumptions that determine the level of the accrued pension liabilities are the differential between the discount rate and the assumed indexation parameter (wage growth, inflation or other) and survival probabilities. For countries where the public pension system has accumulated financial reserves, the existing assets are subtracted.

\section{Measuring defined benefit liabilities in the private sector}

Defined benefit liabilities are regularly calculated in countries with funded private pension schemes where the information is necessary in order to comply with tax rules as well as to meet the standards for minimum funding imposed by regulators. ${ }^{20}$ In addition, there is likely to be some incentive for companies to know their own funding status, and shareholders may demand to have an accurate and thorough accounting of these liabilities. Finally, the need to assess the value of individual worker benefits may arise if workers demand to know what pension rights they have accrued or if they move to another company and are allowed to take their accrued benefits with them. This subsection briefly reviews approaches, issues, and experiences in measuring private-sector defined benefit pension liabilities in selected countries.

An example of the legal incentives to calculate such liabilities is found in the complex 1974 US legislation known as the Employee Retirement Insurance Security Act (ERISA). ERISA set minimum and maximum funding ratios along with rules about how to pay off the liabilities of terminated plans. The 
minimum funding requirements are intended to protect the taxpayer from abuse of PBGC insurance while the maximum limit reduces possible tax expenditures that could arise as companies 'overfund' plans enjoying preferential tax treatment.

In addition to funding issues, some rules are designed to inform investors. The US Financial Standards Accounting Board (FASB) has, since 1989, required that the unfunded liability appear on firms' balance sheets (Warshawsky, 1989). Other reporting requirements stem from the need to prove that pension plans satisfy tax-exempt criteria. This is true, for example, in Germany and Japan, where properly documented 'book reserves' are required in order for schemes to qualify for favorable tax treatment. In Japan, as much as 40 per cent of the 'book reserves' are tax deductible (Murakami, 1990).

The private sector methods used to calculate the pension liabilities affect the way these liabilities are financed, or the so-called 'actuarial cost methods.' This is the umbrella term used in the USA to describe 'the method of allocating the cost of a defined benefit pension plan to each year of the plan's existence in an orderly fashion' (Archer, 1991). Examples of the methods available include PAYG, terminal funding (where lump-sum contributions equivalent to the estimated present value of the annuity are made as the employee retires), and book reserve, where liabilities are entered as loans to the plan sponsor. The PAYG method is used by occupational pension schemes in France, while book reserve schemes are prevalent in Japan and Germany. The actuarial cost method will influence the way the unfunded liability is financed over time but not the value of the liability itself.

The different types of liability calculations will reflect the objectives of the regulators and tax authorities. This is apparent in the most common methods of calculating the pension liability. These can be usefully divided into three general categories.

The 'going concern' liability includes the present value of benefits already earned by current participants as well as the benefits future participants are expected to accrue during their working lives. It is the most ambitious of the three liability estimates and clearly involves many assumptions about future participation in the plan over a potentially infinite time horizon. This method generates a liability that can then be equated to the stream of pension contributions over the same period yielding the concept of actuarial balance used by some public PAYG schemes. ${ }^{21}$ The underlying premise of this calculation is that these schemes will never be terminated.

The present value of anticipated benefit payments to current participants is similar to the first method in that it includes future accrual of benefits and, implicitly or explicitly, involves assumptions about future earnings growth, indexation of benefits, and other variables that impact the stream of future benefits. It differs in that it does not attempt to project these factors for new participants, who are ignored completely. Obviously, the present value of expected benefit payments to current participants will be lower than the liabilities generated by the going concern method due to the exclusion of future participants.

The accrued liability to current participants prorates future benefits by the years of service out of the potential years of service. Minimum vesting periods may also be taken into account. Since full vesting and maximum accrual is achieved at the time of initial benefit award, the liability to the stock of 
current beneficiaries should be equivalent to the present value of anticipated future payments. However, since the method prorates future benefits for active participants, the accrued benefit liability should always be smaller than the present value of expected benefit payments generated by the first two liability calculations mentioned above.

Of the three concepts, the accrued liability method should yield the lowest gross pension liability — that is, before taking into account anticipated contribution revenues. This category can be further subdivided into at least two groups. The first, referred to here as the continued-accrual liability, values the accrued liability as if the scheme had continued into the future. The second category, the accrued termination liability, assumes just the opposite - that the scheme is terminated at the time of valuation. The main difference between the gross liability estimate in the two cases is that the continuation of the plan implies that future retirement behaviour, job loss, pre-retirement mortality or disability and other factors could be taken into account. In other words, as defined here, the termination liability would be greater than the continued accrual liability if, as would normally be the case, the latter includes assumptions that would reduce the number of fully vested, full career workers.

Another important question is whether the method chosen takes into account projected wage increases. In the case of the accumulated benefit obligation, or $\mathrm{ABO}$ as it is known in the US context, future salary increases are ignored. Another version of the accrued liability would take into account future salary levels but not future increases due to post-retirement indexation. This is known as the Projected Benefit Obligation, or PBO.

Finally, one could take into account post-retirement adjustments, as is commonly done in the Netherlands. This is known as the Indexed Benefit Obligation, or IBO. ${ }^{22}$ The accumulated plan benefit method advocated by the US Financial Accounting Standards Board (FASB) is a continued accrual liability that ignores future salary increases.

Table 3 compares minimum funding rules in various OECD countries as described in Davis (1995). Not surprisingly, the actuarial assumptions used to calculate these different liabilities also vary across and within countries. In the Netherlands, a maximum discount rate of 4 per cent is allowed for actuarial purposes (Zweekhorst, 1990). In the United Kingdom, pension actuaries are given wide discretion regarding most of the assumptions. Illustrations from the USA show that actuarial assumptions are not arbitrary and stem from incentives to overfund or underfund in order to take advantage of tax exemptions or deal with firm-specific cash-flow problems. To the extent that accounting standards and government regulations allow it, private pension plans will invariably choose the most favourable methods and assumptions for tax or liquidity purposes.

For example, firms wishing to reduce contributions in a particular year in order to make their balance sheets look more favourable often change interest rate assumptions in a way that reduces expected liabilities or increases expected assets. When the discount rate is not set at a specific level, the firm's actuary can increase its assumed rate of return on investments while simultaneously discounting future benefit promises at a higher rate. Anecdotal (Willinger, 1992) and econometric (Feldstein and Morck, 1982) evidence of this phenomenon has been documented in the USA, and the practice has been observed in US state and local governments. 
Table 3: Funding rules for private pensions in selected OECD countries

\begin{tabular}{ll}
\hline Country & Regulation of funding \\
\hline United States & $\begin{array}{l}\text { Funding of ABO obligatory. Maxium } 50 \text { per cent overfund of the insurance premia if } \\
\text { underfunded }\end{array}$ \\
United Kingdom & $\begin{array}{l}\text { Maximum } 5 \text { per cent overfund of PBO or IBO. Funding only obligatory for part of } \\
\text { social security. }\end{array}$ \\
Germeny & Funding obligatory up to PBO. Option of book-reserve funding. \\
Japan & Tax exempt up to ABO only. Option of book-reserve funding. \\
Canada & Maximum 5 per cent overfunding of PBO. Funding obligatory. \\
Netherlands & Funding obligatory for PBO. IBO usually funded. \\
Sweden & IBO is funded. Contribution rate is 5-yearly to balance fund. \\
Denmark & Irrelevant as funded contribution; benfits must be funded. \\
Switzerland & Funding only obligatory for ABO; PBO usually funded. Four per cent to accounts \\
Australia & annually. \\
France & Irrelevant as defined contribution; minimum contribution rate. \\
Italy & Funded company schemes forbidden; book-reserve funding subject to \\
discrimination.
\end{tabular}

Source: Davis (1995), pp. 94-95

In addition to the assumptions regarding future salary effects on pension benefits and the interest rate used, the calculation of the accrued termination liability requires the use of mortality tables. These may not always reflect the special characteristics of the covered population of the scheme, for example when unisex mortality tables are used in an industry that has a disproportionate number of males or females. In addition, systematic relationships between occupation, income and other factors affecting mortality rates will influence the true value of the liability.

The private sector experience regarding valuation methods of unfunded pension liabilities provides some useful lessons for those attempting to do the same for the public sector. First, it is clear that a variety of methods are used across countries and that the choice of method will lead to significant differences in the value of the liability. It is also apparent that certain rationale, such as the need to provide information for investors, are relevant for government mandated schemes. Even when private pension liabilities are not stated clearly, the market appears to take them into account. This is probably true for public pension liabilities as well, but there is no research to substantiate this assertion, partly because cross-country IPD estimates are not available. Finally, from a practical perspective, some of the methods will be easier to apply in a standardised manner across countries. The next subsection reviews attempts to apply some of these valuation techniques to public pension schemes.

\section{Estimates of pension liabilities in the public sector}

Country estimates exist for all three types of public pension liabilities described in Table 1 - unfunded defined benefit schemes and guarantees for voluntary and mandatory private schemes. ${ }^{23}$ This section briefly reviews some of the existing cross-country estimates that have been made for public defined benefit schemes.

The implications of the IPD for fiscal sustainability have motivated several cross-country studies (Table 4). The earliest was the OECD study by van der Noord and Herd (1993) that calculated the unfunded pension liabilities of seven industrialised countries in 1990. It presents a type of gross pension liability based on a 
Table 4: Estimates of implicit pension debt and general government debt, selected OECD countries (per cent of GDP)

\begin{tabular}{|c|c|c|c|c|c|}
\hline Country & OECD (ABO) & IMF (PBO) & Kune (PBO) & Kune (ABO) & $\begin{array}{l}\text { General Gross } \\
\text { Debt }^{\mathrm{b}}\end{array}$ \\
\hline Belgium & - & - & 101 & 75 & 136 \\
\hline Canada & 121 & 94 & - & - & 96 \\
\hline Denmark & - & - & 117 & 87 & 69 \\
\hline France & 216 & 265 & 112 & 83 & 48 \\
\hline Greece & - & - & 245 & 185 & 114 \\
\hline Ireland & - & - & 78 & 55 & - \\
\hline Italy & 242 & 357 & 207 & 157 & 129 \\
\hline Japan & 162 & 166 & - & - & 83 \\
\hline Luxembourg & - & - & 219 & 156 & - \\
\hline Netherlands & - & - & 144 & 103 & 79 \\
\hline Portugal & - & - & 128 & 93 & 71 \\
\hline Spain & - & - & 129 & 93 & 63 \\
\hline Sweden & - & 131 & - & - & 92 \\
\hline United Kingdom & 156 & 117 & 92 & 68 & 46 \\
\hline United States & 113 & 106 & - & - & 69 \\
\hline West Germany & 157 & 221 & 186 & 138 & 50 \\
\hline
\end{tabular}

${ }^{a}$ Refers to sum of present liability to pensioners and current workforce.

${ }^{\mathrm{b}}$ General government gross public debt in 1994 from Mussa and Masson (1995).

definition similar to the accrued benefit obligation $(\mathrm{ABO})$ described above, alongside a net pension liability measure based on projections through the year 2150. In this particular case, the ABO method takes into account future wage growth, mortality rates, and existing public pension reserves. The authors find that the accrued pension rights are roughly double the conventionally defined public debt.

The International Monetary Fund calculated the pension debt for eight OECD countries (Chand and Jaeger, 1996). Again, both net and gross concepts are presented and found to be large relative to conventional public debt. The gross liability concept is calculated based on projected benefit payments to current retirees and workers. Projected new pension rights are also included in the gross liability calculation but are excluded here for comparability.

Finally, Kune (1996) calculated a continued accrual liability using both $\mathrm{PBO}$ and $\mathrm{ABO}$ type definitions for 12 European Union members in 1990. The covered population over 25 years of age is considered and benefits for survivors under age 65 are not taken into account. The current value of average real pensions is used for the calculation of workers' accrued rights, and future increases in life expectancy are not taken into account. The ABO method prorates the $\mathrm{PBO}$ value by the ratio of number of years of participation in the scheme to the assumed maximum 40 years of participation. It is not clear if changes due to age earnings profiles or other factors (unemployment, maternity periods, etc.) are taken into account. The prorata factor is based on age rather than actual contribution history.

It is interesting to note some of the differences in the results. Kune (1996) reports the lowest IPD figures, although Greece is found to have a very large IPD. This seems to be caused by several factors: first, there are slight differences in the discount rates, with the OECD study using 4 per cent but falling step-wise after 2050 to 3 per cent and Kune remaining at 4 per cent throughout. Secondly, the OECD study takes into account future earnings growth, while 
Kune uses the current real value of pensions for both $\mathrm{PBO}$ and $\mathrm{ABO}$ calculations. Thirdly, Kune does not consider increasing life expectancy, while the OECD study uses population projections from the World Bank that should incorporate such changes.

While these factors explain some of the differences, others are based on definition. The French IPD in the Kune study excludes the supplementary regimes, while this is included in the OECD study. The decision by the OECD authors seems correct given that these are state-mandated, pay-as-you-go schemes. By their nature, they give rise to all of the same intergenerational fiscal concerns as the centrally managed PAYG schemes and should be counted as part of the IPD. A significant difference is also apparent in the case of the United Kingdom. The OECD study finds a much higher IPD figure than Kune that is not explained by discount rate differences.

Highlighting the importance of definitions, the IMF study covers a smaller portion of the overall public pension schemes than the OECD study. For example, the IMF projections exclude about one-third of spending in the United States, the United Kingdom, Canada, and Germany, and almost 40 per cent of Swedish pension spending.

Several important conclusions can be drawn from the results. First, the IPD is found to be very large regardless of the methodology or definition. Secondly, there is a significant degree of variation across the countries. Thirdly, the estimates are quite sensitive to methodology and definitions. Finally, it is clear that the projection of benefits, especially for workers, requires many strong assumptions and is very data intensive. In each of the studies, stylised models were used instead of the actual eligibility and benefit rules of each system in making the projections.

\section{Standardised international estimates of IPD}

The previous sections have highlighted the importance of good IPD estimates but have also revealed that no accepted and universally applied methodology has yet emerged. As a result, international estimates vary in terms of concepts, assumptions, applied models and, therefore, in the estimated magnitude of the IPD. This section suggests using the accrued-to-date or termination liability and proposes a pragmatic methodology to estimate IPD in an internationally comparable manner. Estimates for 24 countries are presented from a variety of regions and income levels.

\section{Towards a practical termination liability approach to IPD}

A practical termination liability approach is suggested for international comparisons of IPD for four main reasons. It is less prone to meddling, avoids questionable assumptions about the revenue side, does not require projections of many future variables, and most importantly, is the measure most relevant for pension reformers.

The estimated IPD should answer the question, "What is the present value of the payment stream that the pension scheme will have to pay current participants and their survivors for the contributions made up to the current date, provided the rules of the scheme stay the same?' This definition includes probabilities that current contributors may die or become disabled before reaching pensionable age. It also includes future changes of the payment stream due to any legislation enacted prior to the year for which IPD is being 
calculated. ${ }^{24}$ An alternative definition of termination liability would be the amount required today to pay off all members of the scheme (for example, the Chilean 'bonos de reconocimiento' to compensate voluntary switchers to the new funded scheme for acquired rights under the old one). ${ }^{25}$ In some countries, this type of valuation has produced a lower ex-post IPD because individuals have accepted less than the face value of their pension promises in the process of privatisation. ${ }^{26}$ Since this discounting depends on the credibility of the scheme in each particular country, we choose to ignore this and consider the termination liability here as an upper bound. ${ }^{27}$

Using the gross liability in a termination context as opposed to the net concept preempts the potential complications of projecting the revenue stream for each country. This in turn avoids entering into prolonged discussions about cross-country differences in issues such as projected coverage rates and evasion, or how to deal with government transfers to the pension scheme. Many schemes are designed to cover the gap between contributions and pension payments with central budget transfers or even earmarked non-payroll taxes. Austria, Germany, and Switzerland have public pension schemes designed to be 'unbalanced' from the standpoint of a pure pay-as-you-go model. France earmarks a wealth tax to finance its social security programmes, while Argentina earmarks certain consumption taxes. In this situation, in order to calculate future earmarked revenues, it would be necessary to project the revenues from other earmarked, non-payroll taxes. Most importantly, it requires a much larger number of rather heroic assumptions regarding future compliance rates and other revenue-side factors. In most developing countries, an estimated net liability/actuarial balance could move from positive to negative with a relatively small increase in evasion.

Minimising the role of assumptions on the expenditure side is another reason for using the termination concept. Under all other concepts, the present value of future expenditure for an arbitrarily chosen period requires projection of future labor market participation, including retirement behavior, benefit levels, demographics, coverage rates, and many other variables. Making consistent assumptions in a cross-country context is almost impossible. Using the termination concept avoids many of these problems since there is no need for projections of many future variables that will affect the value of the pension promise. The one exception in our calculations is mortality rates; here, we apply projected mortality rates that usually incorporate improvements in life expectancy.

Finally, and perhaps most importantly, the termination liability is the most robust indicator for measuring the impact of a fundamental pension reform that involves a shift from a pay-as-you-go, defined benefit scheme to a privately-managed and funded pension scheme. To the extent that such terminations are likely to occur, this measure is a useful baseline for the reform debate and for the fiscal/macroeconomic analysis of the reform proposal. The partial or full termination of pay-as-you-go schemes has begun in ten Latin American countries, at least four former socialist countries in Eastern Europe or Central Asia, the United Kingdom, and Sweden. ${ }^{28}$ It is being planned or seriously discussed in at least a dozen other countries including the USA. Whether or not such a reform is implemented, however, the emphasis on already acquired pension rights versus rights yet to be acquired seems appropriate given 
the relative difficulty in changing the former relative to the latter. ${ }^{29}$

\section{Methodology, assumptions and model for calculating the IPD}

A detailed description of the methodology used to calculate the IPD is found in the Appendix along with data requirements, assumptions, and a description of the model. As mentioned, we have opted for the gross termination concept where the obligations of the public pension scheme for all current members of the scheme are estimated.

There are two main components of the IPD in this context: The first is a relatively straightforward calculation of the present value of the annuity stream paid to current living pensioners, including disabled, survivors, and old age/retirement pensioners. Using ageand sex-specific age cohorts (one year), the payments made to each cohort are tracked until the last person in the youngest cohort has died ${ }^{30}$ and the present value of the payments promised to them is calculated under different discount rate assumptions. ${ }^{31}$

The second component, the obligations to current members of the scheme who have not yet begun to receive benefits, is more complicated. One approach would be to prorate the obligations to current contributors based on a projected number of future contributions and wage growth and application of the existing benefit formula. However, this method ignores those individuals that have not contributed in the current year but who nevertheless have acquired rights to a pension based on earlier contributions.

In order to account for these 'dormant members' and to reflect more accurately the actual observed years of contribution for retiring cohorts in each country, the estimated IPD for non-retired members is 'backed out' by discounting projected benefit spending on individual cohorts and prorating these by the number of contribution years that can be assigned to a particular cohort. For example, the present value of the benefits paid to the cohort of 50-year old males would be projected until the entire cohort is assumed to have died. Then the current accumulated number of contribution years for the same cohort in the year for which the IPD is calculated is divided by the eventual number of contribution years at retirement. This is done to prorate the present value of projected expenditures in line with obligations already incurred at the moment of the hypothetical termination. The result is the estimate of the IPD for the current active or dormant non-retired members.

Wage growth and the discount rate are the two important assumptions for estimating IPD. Real versus nominal wage growth matters in case of price indexation of benefits and non-wage valorisation of wage records for initial benefit calculation. While legal indexation rules differ between countries, actual implementation often deviates from the rules, rendering identical assumptions a useful benchmark. For this reason we assume in the main scenario calculation that both wage records and benefits are wage indexed, rendering the estimated IPD an upper bound for a chosen discount rate; the results for other indexation assumptions are presented in the Appendix. The selected alternative discount rates are 2, 4 and 5 per cent, respectively. ${ }^{32}$ Using a higher discount rate clearly reduces the estimated IPD. But if all or part of the IPD were to be made explicit and debt financed in the course of a pension reform, a higher discount rate would increase the 'true transition deficit' which is the product of interest rate-wage growth difference and the stock of explicit pension debt. These 
Table 5: Public debt, pension spending and pension debt for 24 developing countries for various years during the 1990s

\begin{tabular}{|c|c|c|c|c|c|}
\hline \multirow[b]{2}{*}{ Country } & \multirow[b]{2}{*}{ Public debt } & \multirow{2}{*}{$\begin{array}{l}\text { Pension } \\
\text { spending }\end{array}$} & \multicolumn{3}{|c|}{ IPD by discount rate } \\
\hline & & & $2 \%$ & $4 \%$ & $5 \%$ \\
\hline \multicolumn{6}{|c|}{ As share of GDP } \\
\hline Brazil & 24 & 7 & 500 & 330 & 275 \\
\hline Ukraine & 15 & 9 & 474 & 328 & 279 \\
\hline Slovenia & 11 & 11 & 429 & 298 & 255 \\
\hline Macedonia & 44 & 9 & 441 & 291 & 244 \\
\hline Poland & 43 & 12 & 379 & 261 & 220 \\
\hline Romania & 18 & 6 & 386 & 256 & 214 \\
\hline Malta & 49 & 5 & 356 & 234 & 194 \\
\hline Uruguay & 19 & 14 & 310 & 222 & 193 \\
\hline Slovakia & 21 & 8 & 304 & 210 & 179 \\
\hline Hungary & 86 & 9 & 300 & 203 & 171 \\
\hline Croatia & 25 & 11 & 274 & 201 & 175 \\
\hline Estonia & 4 & 9 & 368 & 189 & 163 \\
\hline Krygyz Rep. & 36 & 7 & 282 & 185 & 154 \\
\hline Moldova & 31 & 8 & 229 & 159 & 136 \\
\hline Lithuania & 14 & 7 & 221 & 155 & 134 \\
\hline Nicaragua & 260 & 2 & 220 & 131 & 104 \\
\hline Cosa Rica & 32 & 2 & 203 & 121 & 97 \\
\hline Turkey & 45 & 5 & 190 & 116 & 96 \\
\hline Philippines & 53 & 1 & 185 & 107 & 81 \\
\hline Senegal & 60 & 2 & 109 & 75 & 65 \\
\hline Ecuador & 65 & 1 & 103 & 63 & 51 \\
\hline Mauritius & 35 & 3 & 63 & 47 & 42 \\
\hline Korea & 9 & 1 & 57 & 33 & 26 \\
\hline Morocco & 70 & 1 & 50 & 32 & 26 \\
\hline
\end{tabular}

Source: Own calculations and public debt based on IMF (1999) and World Bank (1999).

are the additional budgetary resources needed to avoid an increase in the total debt (implicit plus explicit) as a per cent of GDP (Holzmann, 1998). ${ }^{33}$

To produce comparable estimates for different countries, the same model should be used. Country-specific models lack the common structure and often common assumptions for cross-country comparisons. On the other hand, cross-country estimates of IPD to date rely on stylised presentations of the pension scheme(s) under investigation, rendering the results insensitive to country particularities. The following estimates are based on the World Bank's Pension Reform Option Simulation Toolkit (PROST), a model that strikes a balance between the two polar cases. It is flexible enough to incorporate most of a country's idiosyncratic pension system features but imposes a common structure on all countries in the analysis. In most cases, the model has been tested in the context of pension reform analyses.

\section{IPD estimates for 24 developing countries}

Table 5 presents the IPD estimates for 24 developing countries under alternative discount rate assumptions and compares them with official public debt, expenditure levels, and existing financial reserves (all in percent of GDP). Several results stand out.

First, the estimated IPD is large relative to national incomes in our sample of countries but there is a huge range. Using the 2 per cent discount rate, Brazil's IPD is 500 percent of GDP, ten times more than Morocco. Even 


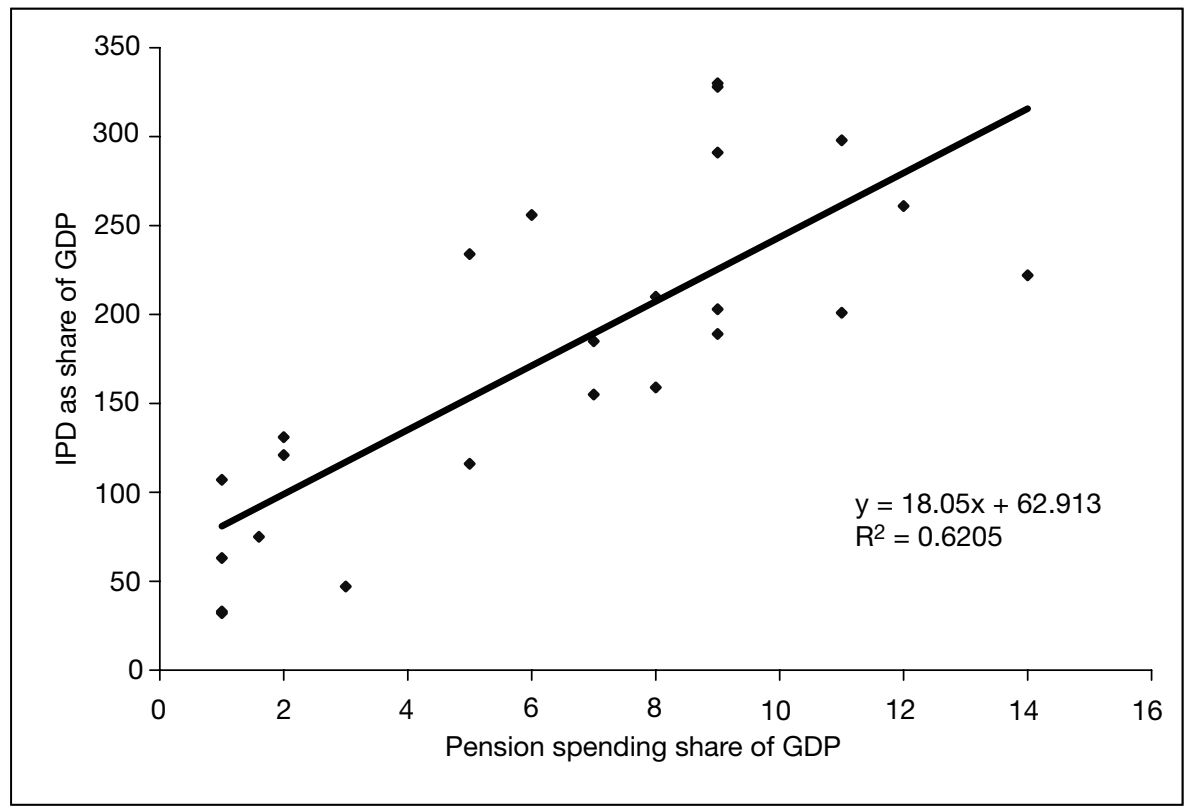

Figure 1 Pension spending and IPD estimates for 24 countries

using the higher, 5 per cent discount rate, 16 out of 24 countries had IPDs greater than national income.

Not surprisingly, the former socialist countries and especially Central Europe, have the highest IPD burdens measured this way. Of the 11 countries with ratios of at least 200 per cent, nine of them are from this region. This reflects the high labour force coverage that characterised countries in this region and relatively generous benefit levels, combined with an aging population. Uruguay is another country with a large state apparatus and high social expenditures and has the oldest demographic structure in Latin America. At the other end of the spectrum are younger countries like Senegal and Morocco where coverage is much lower than what had been found in pre-transition Central Europe.

Nevertheless, the levels of pension debt even in these countries is too significant to ignore.

IPDs are high relative to conventionally defined public debt for most countries. Only three countries, Ecuador, Morocco and Nicaragua, have higher explicit public debt when using the 4 per cent discount rate case. This result highlights the importance of this indicator for a proper assessment of long-term fiscal sustainability. It is also a measure of just how difficult a rapid shift from an unfunded system to a funded pension scheme would be in some countries. Last but not least, these figures suggest that pension debt or wealth could be a significant factor in determining savings behaviour in many developing countries.

To what extent do these estimates simply reflect differences in current spending levels? While there is the expected positive correlation between the IPD and pension expenditure, the fitted line in Figure 1 below suggests that current spending is not a reliable predictor of pension debt in this sample of countries. This probably is due to the differential maturity of the schemes. A drastic example is Korea, where full 
benefits in the main scheme covering private sector workers will be first paid in 2008 (20 years after introduction) and hence current pension expenditure is very low, while IPD after ten years of introduction already amounts to 47 per cent (with reserves equal to only 10 per cent of GDP). Beside maturity, differences in these ratios are also due to demographic aging patterns. A higher old-age dependency ratio increases, other things equal, both the IPD and expenditure shares, but differences in future dependency ratios first impact IPD before also translating into higher pension expenditure shares.

Finally, it is important to note that alternative indexation of wage records and benefits changes the estimated IPDs but not dramatically in most countries (see Appendix Table A). Moving from wage to price indexation of benefits reduces IPD, on average, by some 15 to 20 per cent, with a lower reduction the higher the discount rate.

Current pension spending levels will fail to reflect reforms that are being gradually phased in or changes to indexation which have large compounded impacts. The IPD numbers capture this, therefore providing a more accurate assessment of the long term burden compared across countries. ${ }^{34}$

\section{Conclusion and directions for future research}

The results of the last section show that the IPD represents a fiscal burden that cannot be ignored in low- and middle-income countries. There are many compelling reasons for reporting a standardised measure of the IPD alongside the commonly cited public debt indicators.

First, social insurance obligations are often the largest single unreported liability in the public sphere. Even in countries with small, immature schemes, these obligations are the fastest growing of these liabilities. The growth is determined by the maturation of the schemes but also by population aging.

Secondly, the IPD provides a tool with which to evaluate pension reform that does not currently exist. Reductions to the IPD due to marginal changes such as increasing the effective retirement age or altering the benefit indexation rules could be readily measured. More importantly, however, an IPD measure allows for a better understanding of the impact of systemic changes that involve partial privatisation of the unfunded public scheme. Currently, the accounting is biased towards the unfunded schemes since as IPD is made explicit, the target debt indicator rises in the short run. By showing that the IPD is reduced by a similar magnitude, a clearer picture of the effect of reform on long-term fiscal sustainability can be presented.

Thirdly, a reported IPD might discourage the creation of new liabilities as stop-gap measures during crises (for example, early retirement in Eastern Europe during the transition). Currently, the accounting provides a great temptation to choose off-the-book liabilities instead of going through the effort required to issue tradeable debt and control the size of explicit public debt.

Finally, standardised IPD estimates would add an element of transparency to publicly managed, defined benefit schemes around the world that is sorely lacking. Most workers (and most voters) in countries with pay-as-you-go pension schemes are not aware of the magnitude of these liabilities. Including the IPD as a footnote to government accounts would provide the type of useful disclosure often required of publicly listed firms in their annual reports to shareholders. The standardised IPD would allow cross-country comparisons, including in 
the area of sovereign risk rating.

This raises several interesting issues for future research. On the one hand, to the extent that the financial markets experienced fiscal illusion, alerting them to the existence of debt could have a negative impact on credit ratings, borrowing spreads, and direct investment flows. More likely, however, is that financial markets already take a crude measure of the IPD into account. Reporting it would reduce uncertainty, which would be positive on the whole.

The reaction of financial markets to making the IPD explicit has not been studied. Further research analogous to that in the existing literature on the impact of unfunded pension liabilities on firm valuation would be useful. Previous studies suggest that the markets do take unfunded pension liabilities into account when determining share prices (see Feldstein and Seligman, 1981). It seems reasonable to expect that the financial markets are already considering IPD, especially in countries where it is extremely large and the repayment schedule is concentrated in a period relevant for the yield curve on government paper. $^{35}$

A more important question perhaps, is the reaction of the financial markets to a radical pension reform in which IPD is converted into an explicit, observable debt. Again, there does not seem to be research on this question for the countries in which radical reform actually took place. One testable hypothesis is that the reaction will depend on whether the markets perceive that the IPD had been reduced in the reform process so that the overall balance sheet of the government had improved.

Last but not least, systematic measures of IPD would allow for an extension of the literature on the impact of pay-as-you-go pension schemes on national savings. The equivalent of
Feldstein's social security wealth variable would now be available for a large set of countries and eventually for multiple years. Along with parallel research based on household survey data, these aggregate indicators could be used in cross-country studies of the determinants of savings rates.

We conclude that some reasonable measure of IPD should be reported in a standardised way for low and middle income countries, for example, as a memorandum item standard fiscal accounts such as the IMF's GFS statistics. Access to this indicator will improve our understanding of savings, financial market behaviour and fiscal sustainability. It will help inform the reform debate in each country. Moreover, it will help reformers design reforms with feasible transitions and assess the fiscal impact of their options. Had an IPD measure been as clearly reported as public deficit and debt targets, fewer reforms would be needed and fewer pension promises would have to be broken.

\section{Acknowledgment}

Earlier versions of this paper have profited from various comments and suggestions from inside and outside the World Bank. Special thanks go to Bernd Raffelhueschen (Germany) and Klaus Schmidt-Hebbel (Chile). All remaining errors are our doing. The views expressed are entirely those of the authors and do not necessarily reflect those of the World Bank and its Board of Executive Directors.

\section{References}

1 Perhaps the most pressing need is felt in the European Union where an increasing number of economists consider it important to consider unfunded pension liabilities alongside conventional debts and deficits in the context of monetary union and related fiscal policy discussions. Disney (forthcoming) argues persuasively for standardized measures for EU countries.

2 There are also a number of non-contributory pension schemes for civil servants that are not based on earmarked revenues and so can be considered to be unfunded from the beginning.

3 The closest example the authors are aware of is the civil service pension scheme in South Africa which has a reported funding ratio of almost 75 per cent. 
4 See for example, Boskin (1982), Hills (1984), and Kotlikoff (1986).

5 Even in the case of war-torn Bosnia, payments continued during the war and liabilities for missed payments have been recorded.

6 See for example Schwarz and Demirguc-Kunt (1999).

7 This is not just an academic issue. For example, a 1996 UK Parliamentary report (Social Security Committee, 1996) entitled 'Unfunded Pension Liabilities in the European Union' questioned the extent to which the liabilities could be reduced in the face of industrial unrest, citing protests in Germany and France.

8 Rizzo (1990) tests for the determinants of pension liabilities using a public choice framework.

9 For a review of literature see World Bank (1994) and Schmidt-Hebbel and Serven (1999).

10 This is true for those who argue for a life-cycle consumption type behaviour as well as for those who hold that Ricardian equivalence type behavior exists.

11 There are few examples of this type of assessment for actual pension reforms. One example is Beltrametti (1996) which looks at the impact of the Dini and Amato pension reforms on an IPD measure in Italy.

12 For example, see Banks et. al. (2000).

13 See Yun (2000) for example.

14 Palacios and Pallares (2000).

15 In addition to the minimum pension guarantee, the Chilean scheme guarantees the payment of pensions in case a life insurance company providing annuities goes bankrupt. The guarantee covers 100 per cent of the annuity up to the minimum pension and 75 per cent of the annuity in excess of the minimum (see Chilean Superintendency of AFPs, 1996). Argentina has a similar guarantee for the annuity stage of its system.

16 This concept is in line with proposals by Buchanan (1968) and others to make the accumulating obligation explicit in the form of special non-tradeable bonds with a prescribed interest rate.

17 Changes in unfunded liabilities of the public employees' superannuation scheme are reported under the new accrual accounting system, however.

18 Alternative terminology on pension liabilities taken from the US private sector context using roughly equivalent concepts is: (a) accrued termination liability; (b) present value of anticipated benefit payments to current participants; and (c) 'ongoing concern' liability. See Section III.3.

19 In the steady state, with an actuarially balanced pension system without financial reserves, both accrued-to-date liabilities (the gross implicit pension debt) and the net-social security wealth coincide since the present value of further liabilities resulting from future contributions and the present value of future contributions cancel out.

20 These are often not equivalent.

21 The US Social Security programme uses this method computed over a 75 year period.
22 See Bodie (1990) for a discussion.

23 For example, Ippolito (1984) presents estimates for the private sector guarantees of the Pension Benefit Guarantee Corporation (PBGC) in the US. Wagner (1991) estimates of the present value of the future costs of the minimum pension guarantee in Chile.

24 For example, where the retirement age increase is being phased in gradually and will rise in the future, this would be taken into account in the calculation.

25 For a detailed description of the Chilean recognition bond see Arena de Mesa and Cullel (1993).

26 An interesting feature of a public scheme termination is the revealed value of accrued obligations in the pension scheme in the process of a voluntary, opt-out to a funded, defined contribution scheme. In many cases, individuals appear to discount the public pension promises relative to the types of IPD measures discussed here, reflecting a political risk associated with the promise. For a discussion, see Palacios and Whitehouse (1998).

27 Another way to think about it is that pension debt, like conventional bonds are risky and that the probability of default varies by country and over time. In a privatisation with a voluntary switch, a secondary market of a sort is created for the IPD and this has often 'traded' at below face value.

28 See Palacios and Pallares (2000) for further details.

29 In the last decade, the value of defined pension benefits in public schemes have been revised downward for future generations of retirees in the United Kingdom, Japan, Germany, the United States, France, and Italy, to name only a few cases.

30 It is important to note that we are forced to use national mortality tables for these calculations instead of membership mortality experience. The main effect is to understate pension liabilities in countries with lower coverage rates, especially where the distribution of resources is skewed.

31 For survivors a cruder method is applied. We assume that if current payments for survivors constitute 10 per cent of all pension spending, then 10 per cent of IPD is due to survivors. We use this simplification because survivors benefit can be terminated for other reasons than death and modeling this complexity would make the results less transparent with marginal impact on the total IPD.

32 Hence, under the 2 per cent discount rate assumption, wage growth and discount rate are the same, presenting somewhat the upper bound of any estimated IPD. Discount rates of 4 and 5 per cent, respectively, represent discount rate-wage indexation differentials of 2 and 3 per cent, respectively.

33 This assumes steady state conditions in which wage growth equals GDP growth and where the discount rate reflects the market rate of interest for government borrowing.

34 Another relevant measure for the purposes of assessing sustainability is the ratio of IPD to the wage bill subject to contributions. Using this measure highlights the problems of poor countries 
such as Senegal in servicing its IPD despite having a relatively low IPD/GDP ratio.

35 To the extent that this contention is true, the current accounting systems can be said to unjustly penalize reformer countries when multilateral institutions such as the IMF focus on current deficit and conventional debt targets.

\section{Bibliography}

Archer, Michael (1991) 'Chapter 4: Minimum Funding Requirements', in Martin Wald and David Kenty, (eds), ERISA: A Comprehensive Guide. New York: Wiley and Sons.

Auerbach, Alan, Lawrence Kotlikoff, and Willi Leibfritz, (eds) (1999) Generational Accounting around the World. Chicago: University of Chicago Press.

Banks, J., Disney, R. and Smith, Z. (2000) 'What can we learn from Generational Accounts for the United Kingdom?', Economic Journal Features, 110, November, F575-F597.

Beltrametti, Luca (1996) Il debito pensionistico in Italia, Societa Editrice il Mulino, Bologna, Italy.

Bodie, Zvi (1990) 'ABO, the PBO and Pension Investment Policy', Financial Analysts Journal, 46: 27-34.

Buchanan, James (1968) 'Social Insurance in a Growing Economy: A Proposal for Radical Reform', National Tax Journal, 21(4), 386-395.

Chand, S., and Jaeger, A. (1996) 'Aging Populations and Public Pension Schemes', Occasional Paper 147, International Monetary Fund, Washington D.C.

Chilean Superintendency of AFPs (1996) 'Boletín Estadístico' Superintendencia de Administradoras de Fondos de Pensiones, Santiago, Chile.

Disney, R. (forthcoming), 'How should we measure pension liabilities in EU Countries', in Evaluating the long-term sustainability of European pension systems, Kluwer.

Disney, R. (1999) 'OECD Public Pension Programmes in Crisis: An Evaluation of the Reform Options', Pension Primer Paper Series, Socal Protection Discussion Paper, No. 9921, World Bank, Washington D.C.

Davis, E. Phillip (1995) 'Pension Funds, Retirement-Income Security and Capital Markets, an International Perspective,' Oxford University Press.

de Mesa, A. and Cullel, M. (1993) 'Proyecciones del Gasto Previsional 1992-2038; Un Modelo de Simulación para los Bonos de Reconocimiento', República de Chile, Ministerio de Hacienda, Dirección de Presupuestos, Santiago, Chile.

Feldstein, Martin (1974) 'Social security, induced retirement, and aggregate capital accumulation', Journal of Political Economy, 82: 905-26.

Feldstein, Martin, and Randall Morck (1982) 'Pension Funding Decisions, Interest Rate Assumptions and Share Prices', National Bureau of Economic Research Working Paper Series No. 938: 1-44. Cambridge, MA.

Franco, D. 'Pension liabilities - Their Use and Misuse in the Assessment of Fiscal Policies', European Commission, Directorate General for Economic and financial affairs, Economic Papers, n.110.

Hills, J. (1984) 'Public Assets and Liabilities and the Presentation of Budgetary Policy', in Public Finance in Perspective, Report Series No. 8, Institute for Fiscal Studies, London.

Hochreiter, Eduard, Georg Winckler, and Peter Brandner (1998) 'Deficits, Debts and Monetary Union - Some Unpleasant Fiscal Arithmetic', in Guillermo Calvo, Mervyn King, (eds), 'The Debt Burden and its Consequences for Monetary Policy', Houndmills, Basingstoke, Hampshire and London: International Economic Association, MacMillan Press.

Holzmann, Robert (1998) 'Financing the Transition', Social Protection Discussion Paper Series No. 9814. The World Bank, Washington, D.C.

Ippolito, Dennis (1984) 'Hidden Spending: the Politics of Federal Credit', Chapel Hill: University of North Carolina Press.

Kotlikoff, L. (1986) 'Deficit Delusion', in 'What Determines Savings', MIT Press, Cambridge, Massachusetts.

Kotlikoff, Lawrence, and Bernd Raffelhueschen (1999) 'Generational Accounting Around the Globe', American Economic Review, Papers and Proceedings 89(2), 161-166.

Kune, Jan. (1996) 'The Hidden Liabilities: Meaning and Consequences', revised version of a paper presented at the CBP Seminar Series, The Hague (mimeo).

Murakami, Kiyoshi (1990) 'Chapter 8: Severance and Retirement Benefits in Japan', in US Department of Labor, Pension Policy: An International Perspective. Washington, D.C.

OECD (1996) 'Ageing in OECD Countries: A Critical Policy Challenge', Social Policy Studies No. 20, Paris.

Palacios, Robert, and Edward Whitehouse (1998) 'The Role of Choice in the Transition to a Funded Pension System', Social Protection Discussion Paper Series No. 9812. The World Bank, Washington, D.C.

Palacios, Robert, and Montserrat Pallares-Miralles (2000) 'International Patterns of Pension Provision', Social Protection Discussion Paper Series, No. 0004. The World Bank, Washington D.C.

Palmer, E. (2000) 'The Swedish Pension Reform Model: Framework and Issues', Pension Primer Paper Series, Social Protection Discussion Paper, No. 0012, World Bank, Washington D.C.

Rizzo, Ilde. (1990) The 'Hidden Debt', Financial and Monetary Policy Studies, 19.

Dordrecht-Boston-London: Kluwer Academic Publishers.

Schmidt-Hebbel, Klaus and Louis Serven (1999) 'The Economics of Saving and Growth - Theory, Evidence and Implications for Policy', Cambridge University Press.

Schwarz, Anita, and Asli Demirguc-Kunt (1999) 'Taking Stock of Pension Reforms Around the World', Social Protection Discussion Paper No. 9917. The World Bank, Washington, D.C.

Valdes-Prieto, S. (2000) 'The Financial Stability of 
Notional Account Pensions', Scandinavian Journal of Economics, 102(3), 395-417.

Van der Noord, Paul, and Richard Herd (1993) 'Pension Liabilities in the Seven Major Economies', Working Paper No. 142:1-64. OECD Economics Department, Paris.

Wagner, G. (1991) 'La Seguridad Social y el Programa de Pensión Mínima Garantizada', Estudios de Economía 18(1), 35-89, Santiago, Chile.

Washawsky, M. (1989) 'The Institutional and Regulatory Environment of Private Defined Benefit Pension Plans', in U.S. Department of Labor Trends.

Willinger, U. (1992) 'A Simulation Comparison of Actuarial and Contingent Claims Models for Unfunded Pension Liabilities', Quarterly Journal of Business and Economics 31(2), Spring.

World Bank (1994) 'Averting the Old Age Crisis: Policies to Protect the Old and Promote Growth', The World Bank, Washington, D.C.

Yun, Sukmyung (2000) 'Generational Accounting for Korea with Special Reference to Pension Schemes', KIHASA working paper, Seoul Korea.

Zweekhorst, Kees (1990) 'Chapter 10: Developments in Private Pensions in the Netherlands', in US Department of Labor, 'Pension Policy: An International Perspective', Washington, D.C.

\section{Appendix: Methodology of IPD estimation, data requirement, and assumptions}

The methodology used for the IPD estimation is based on several criteria:

- The IPD focuses on expenditures and not the stream of anticipated earmarked revenues.

- The IPD is a termination liability in that it represents the outstanding obligations that would have to be paid in the event that the scheme were discontinued.

- However, in order to avoid the subjective assumptions about the likely value of accrued to date pension liabilities in a real termination scenario, we focus on a 'projected liability', defined as the present value of the expected payment stream to current pension plan participants based on the contributions made up to the current date. This definition includes probabilities that current contributors might die or become disabled before reaching pensionable age. It also includes future changes of the payment stream due to the legislation enacted prior to the year for which IPD is being calculated. We also recognise that this method ignores or reduces the effect of minimum vesting periods and non-linear accrual rate schedules.

- Only pension benefit expenditures are taken into account. Administrative costs and non-pension related activities of the pension scheme are ignored.

- The data requirements should not be too onerous to exclude a large number of countries from the potential sample.

- Assumptions about coverage expansion and contraction that would normally differ across countries should not affect the estimates.

Non-members, defined as everyone who has never contributed (or for whom there is no clear claim to a future benefit) to the scheme at the time the IPD is calculated, are not considered.

\section{Population projections}

An age- and gender-specific population matrix is projected using the current stock of population and assumptions about fertility and mortality. The projection is made until the year 2075 . The end year is chosen such that the current youngest contributors (aged 20 in year 2000) could be followed through until practically everyone in the cohort dies (aged 95 in 2075). All demographic data is taken from World Bank population database (E. Bos, M.T. Vu, E. Massiah, R.A. Bulatao (1994): World Population Projections 1994-95, Johns Hopkins University Press, Baltimore, MD.) 


\section{Projecting contributors and beneficiaries and determining average length of service}

Contributors to population ratios are derived by dividing current stock of contributors by the population of corresponding age and gender. Similar ratios are calculated for pensioners receiving old age, disability and survivors' benefits. It is assumed that these ratios will remain stable for each age/sex specific cohort.

Making a reasonable projection of pensioner numbers is less straightforward. Clearly, the number of pensioners in the future should depend on the current number of active contributors. There might also be a significant number of 'dormant memberships,' which also produce retirees. It is almost impossible to get the data on the number of 'dormant memberships', however, average length of service at retirement may be a good proxy. For example, the same sustained number of active contributors will produce twice as many pensioners if each retiree retires with 20 years of service compared with the scenario where each worker retires with 40 years of service. This is because in the first scenario there are twice as many 'dormant memberships', that is, people spend a large proportion of their adult lives not contributing to the system. Unfortunately, length of service data is also rarely available for the base year and has to be only guessed for the future years.

To be consistent, the following rule was used. First, the cohort with highest coverage was chosen (a person is considered covered if he/she is an active contributor, old age pensioner, or disabled). It was assumed that in the future, coverage in the oldest cohorts will converge to this level. For example, consider a pension scheme that has just undergone expansion in contributor numbers and in which current contributor to population ratio peaks at 70 per cent in the 40-year old-age cohort. Meanwhile, the current old-age pensioner to population ratio peaks at 40 per cent for 68 -year-olds. Then it is assumed that eventually 70 per cent of the population will retire under the pension scheme. If the reverse is true and the scheme has undergone recent contraction where contributor ratio peaks at 40 per cent and the pensioner to population ratio peaks at 70 per cent, it is still assumed that in the future 70 per cent of the population will retire with benefits from the scheme. In these examples, the first scenario will be characterised by much higher length of service at retirement than the second scheme, since the same proportion of the population eventually becoming pensioners is generated by a smaller proportion of contributors relative to population. In short, our methodology assumes that contraction/expansion in the contributor numbers is first translated into lower/higher average length of service and only then into lower/higher number of pensioners. Length of service determined this way is held constant throughout the simulation horizon.

This approach is more reasonable for some countries than for others. For example, in countries in the process of moving from a socialist to a market economy, unemployment gaps and informal labour market activity increased and the number of active contributors declined. However, this decline in coverage mainly affects length of service but not the number of future retirees. The scenario is also appropriate in countries that have recently raised the length of service requirement (Turkey). These countries may find themselves with a greater numbers of contributors, but this is likely to be reflected only partially in the number of future 
pensioners. The greatest impact will instead come via the average length of service periods for new pensioners. On the other hand, countries that have undergone recent coverage expansion among the younger cohorts (for example, Costa Rica and Korea) are more likely to experience the growth in pensioner numbers than growth in length of service.

After the total number of future retirees is assessed, it is distributed over the same retirement pattern (ages of retirement) as observed in the system in the base year. For example, if 20 per cent of all current pensioners retired being 60 years old, it is assumed that 20 per cent of future retirees will also retire at this age. Admittedly, this methodology results in underestimating IPD for immature schemes (Korea), where the current new retirees might be older than the long term trend. In case of ongoing retirement age reform the retirement pattern is adjusted accordingly.

\section{Wage growth, post retirement benefit indexation and discount rates}

It is assumed that there are no gender differentials in wages. The productivity growth is assumed to be 2 per cent per year. On top of that each worker gets a wage adjustment due to seniority, that is equal to 1 per cent of the 20-year-old male's wage. The complication of the seniority adjustment was introduced in order to help differentiate between countries that use short versus long wage histories in their benefit formulas. For example, if the scheme gives a benefit equal to 50 per cent of the average of ten last wages (adjusted to the average wage growth), the total benefit will be less than in the scheme that uses five last wages as a base. This is because the first scheme incorporates wages, that were earned in the earlier years of one's career.
The seniority component in wage growth is the same for all workers in nominal terms. However, per centage-wise, the component is lower for older workers. This corresponds to the actual situation observed in the majority of the labour markets. This non-linearity interacts with different demographic situations in different countries, producing different average wage growth. For example, the countries with rapidly aging labour forces will be experiencing lower average wage growth than others. However, the productivity growth is assumed to be the same in all countries.

Benefits are assumed to be wage indexed. This may appear to seriously skew the results in favour of those countries that actually do index benefits to wages as opposed to prices. However, the relationship that matters is the discount rate relative to the growth of wages. And since the correct discount rate (regardless of whether it reflects government or individuals time preference), would vary across countries, our preference is to remove this 'noise' in favour of a standardised differential between the discount rate and the indexation rule.

In order to test the sensitivity of the magnitudes involved, we have calculated IPD using three different sets of discount rate differentials. The calculations very clearly demonstrate that varying discount rate not only significantly changes the absolute value of IPD, but may also affect the relative position of the country when comparisons are made. For example, using the discount rate of two per cent, the IPD for Croatia was calculated to be 274 per cent, and IPD for Kyrgyz Republic was slightly higher at 282 per cent. However, the term structure of this debt is very different in 2 countries. In Croatia, which has recently started its transition to a significantly smaller PAYG system only 
44 per cent of total debt is due to current contributors. On the other hand in Kyrgyz Republic, where the pension system is being reformed less ambitiously and where the expected aging of population is faster, debt to current contributors constitutes 68 per cent. Clearly, choosing the higher discount rate would reduce the IPD of the Kyrgyz Republic vis a vis Croatia. And indeed, at 5 per cent discount rate Kyrgyz Republic does seem to have a lower implicit pension debt (IPD for Kyrgyz Republic is 154 per cent and IPD for Croatia is 175 per cent). This observation holds true in general. Countries, that are undergoing significant reforms to improve fiscal sustainability are favored in comparisons, when discount rates are low (Croatia, Estonia, Lithuania, and Poland), and countries with immature or expanding systems are favored under higher discount rates (Korea, Malta, Nicaragua, and the Philippines). Countries with young but rapidly aging populations will also look better in comparison at higher discount rates.

\section{Replacement rates}

Replacement rates for new disabled and survivors are held constant and equal to the average observed replacement rates in those groups in the base year. This clearly understates the implicit pension debt for immature schemes, where disability and survivor benefits are expected to grow as length of service rises (for example, Korea). On the other hand it overstates the implicit pension debt for the countries that have recently experienced temporary increase in number of disabled and survivors (for example, Poland and Croatia). (The effect of earlier retirement age dominates, that is, the present value of the average disability pension stream is higher than that of the old age pension stream, because it is being received for a longer time period.) Replacement rates for new old age pensioners are derived using the benefit formula.

\section{IPD for current old age pensioners and disabled}

Each cohort of current old age pensioners and disabled is followed through with the probability of death applied each year. The benefits of remaining beneficiaries are indexed to wage growth. The resulting pension payments each year are aggregated among all cohorts and discounted to the base year, using the appropriate discount rate.

\section{IPD for current contributors}

Each year throughout the simulation horizon the expected number of new retirees and new disabled of each age and gender is derived based on the current beneficiary/population ratios and their benefits are calculated. Given the mortality assumptions and appropriate discount rate we convert these benefits into lump sums, multiply them by the number of new retirees and add all of them up by age, gender and benefit programme, getting the liability of the system to the people retiring that particular year. We then discount this liability back to the base year and take the portion of it that can be considered due to the contribution already paid based on a simple prorating of contributions made over projected contribution history. For example, if the average retirement age in 2020 is 58 , careers usually start at 20 and we are calculating the IPD for year 2000, then we would take the portion $(58-2020+2000) /(58-20)$ of the total liability to the new retirees of 2020 . 
Data and assumptions

\begin{tabular}{|c|c|c|c|c|c|}
\hline & Country & Data & Excludes $^{a}$ & Reforms & $\begin{array}{l}\text { Length of service } \\
\text { in new benefit } \\
\text { estimation }\end{array}$ \\
\hline 1 & Brazil & 1998 & State civil servants $(5 \%)$ & $\begin{array}{l}\text { Benefit formula, LOS } \\
\text { requirements }\end{array}$ & $35 / 30 ; 15$ after $60 / 65$ \\
\hline 2 & Costa Rica & 1993 & & & $28 / 22$ \\
\hline 3 & Croatia & 1998 & $\begin{array}{l}\text { Croatia's defender's } \\
\text { scheme (1\%) }\end{array}$ & $\begin{array}{l}\text { Ret. age, benefit } \\
\text { formula }\end{array}$ & $25 / 24$ \\
\hline 4 & Ecuador & 1998 & & & $37 / 32$ \\
\hline 5 & Estonia & 1998 & & Ret. age & $32 / 29$ \\
\hline 6 & Hungary & 1995 & $\begin{array}{l}\text { Reduced capacity to } \\
\text { work programme }\end{array}$ & Ret. age, multi-pillar & $28 / 25$ \\
\hline 7 & Korea & 1995 & $\begin{array}{l}\text { Military personnel, } \\
\text { private school } \\
\text { teachers }\end{array}$ & $\begin{array}{l}\text { Ret. age, benefit } \\
\text { formula }\end{array}$ & $33 / 20$ \\
\hline 8 & Kyrgyz Republic & 1997 & & $\begin{array}{l}\text { Ret. age, notional } \\
\text { accounts }\end{array}$ & $29 / 20$ \\
\hline 9 & Lithuania & 1998 & & $\begin{array}{l}\text { Ret. age, benefit } \\
\text { formula }\end{array}$ & $27 / 25$ \\
\hline 10 & Macedonia & 1999 & & Ret. age & $23 / 23$ \\
\hline 11 & Malta & 1998 & & & $39 / 30$ \\
\hline 12 & Mauritius & 1998 & Civil servants (10\%) & & $31 / 28$ \\
\hline 13 & Moldova & 1997 & & $\begin{array}{l}\text { Ret. age, benefit } \\
\text { formula }\end{array}$ & $24 / 20$ \\
\hline 14 & Morocco & 1997 & Civil servants & & $29 / 23$ \\
\hline 15 & Nicaragua & 1998 & & & $31 / 26$ \\
\hline 16 & Philippines & 1997 & & & $30 / 25$ \\
\hline 17 & Poland & 1997 & Armed Forces & $\begin{array}{l}\text { Ret. age, notional } \\
\text { accounts }\end{array}$ & $\begin{array}{l}\text { Farm 30/25; urban } \\
\quad 37 / 39\end{array}$ \\
\hline 18 & Romania & 1996 & Farmers $(11 \%)$ & & $25 / 25$ \\
\hline 19 & Senegal & 1998 & & & $13 / 10$ \\
\hline 20 & Slovakia & 1998 & & & $32 / 25$ \\
\hline 21 & Slovenia & 1996 & State (citizen's) pension & $\begin{array}{l}\text { Ret. age, benefit } \\
\text { formula }\end{array}$ & $27 / 25$ \\
\hline 22 & Turkey & 1997 & & $\begin{array}{l}\text { Ret. age, decrease in } \\
\text { disability pension, } \\
\text { benefit formula, } \\
\text { elimination of SYZ } \\
\text { benefit }\end{array}$ & $\begin{array}{l}\text { BK-25 for males; } 20 / 25 \\
\text { and } 15 \text { for females; } \\
\text { ES-25/25; SSK } 23 / 23\end{array}$ \\
\hline 23 & Ukraine & 1998 & & & $35 / 30$ \\
\hline 24 & Uruguay & 1995 & & Ret. age, multi-pillar & $26 / 22$ \\
\hline
\end{tabular}

Source: World Bank database

${ }^{a}$ coverage in parentheses

Most of the studies that attempted to calculate IPD have taken a different approach. They take an individual contributor, assume that he/she will retire at average retirement age and prorate the full benefit at retirement using length of service or age of the contributor to figure out the prorating factor. Then the calculated debt for the individual is multiplied by the number of contributors of the same age. This approach has two downsides. First, the number of contributors usually does not include 'dormant memberships,' that is, people who have been contributing to the system before, but were not contributing the year that the data was collected. Secondly, the approach ignores the fact, that people retire at different ages. As long as accrual rates around the average retirement age are not actuarially fair (usually they are not) the assumption of everybody retiring at the average age introduces unnecessary errors into the calculations. 


\section{Deriving IPD for survivors}

IPD for survivors is calculated in the least precise manner. If the survivor programme represents a certain proportion of pension spending in the base year, the total liability for contributors, disabled and old age pensioners is augmented by the same proportion to get the IPD inclusive of survivors. For example, if in the base year survivor pension payments constitute 20 per cent of all pension payments, then we add implicit pension debt for current contributors, current old age pensioners and current disabled and then multiply this sum by 120 per cent to get the total implicit pension debt.

\section{Data requirements}

- GDP in the base year.

- Average annual insurable earnings (this can differ from average wage in the presence of contribution floors and ceilings).

- Total pension spending in the base year on old age pensioners (by gender), disability (by gender) and survivor schemes.
- Old-age benefit calculation rules.

- Base year population by age and gender.

- Current and projected fertility and mortality by age and gender. Fertility assumption is almost immaterial, since it influences the results extremely little. We have chosen to include it in the list of required variables only because it is readily available whenever mortality data is available. The assumption that some standard fertility path will be the same for all countries would work as well.

- Current stock of active nominal contributors. Here we mean people who are earning pension rights in the base year, even though they might be exempt from contributions. Good examples are soldiers, clergy or mothers on maternity leave. Nominal contributor numbers should exclude 'dormant memberships,' that is, people who have contributed to the pension scheme for some time but are not active during the year for which IPD is being calculated.

- Current stock of beneficiaries by age, gender and type of benefit. 


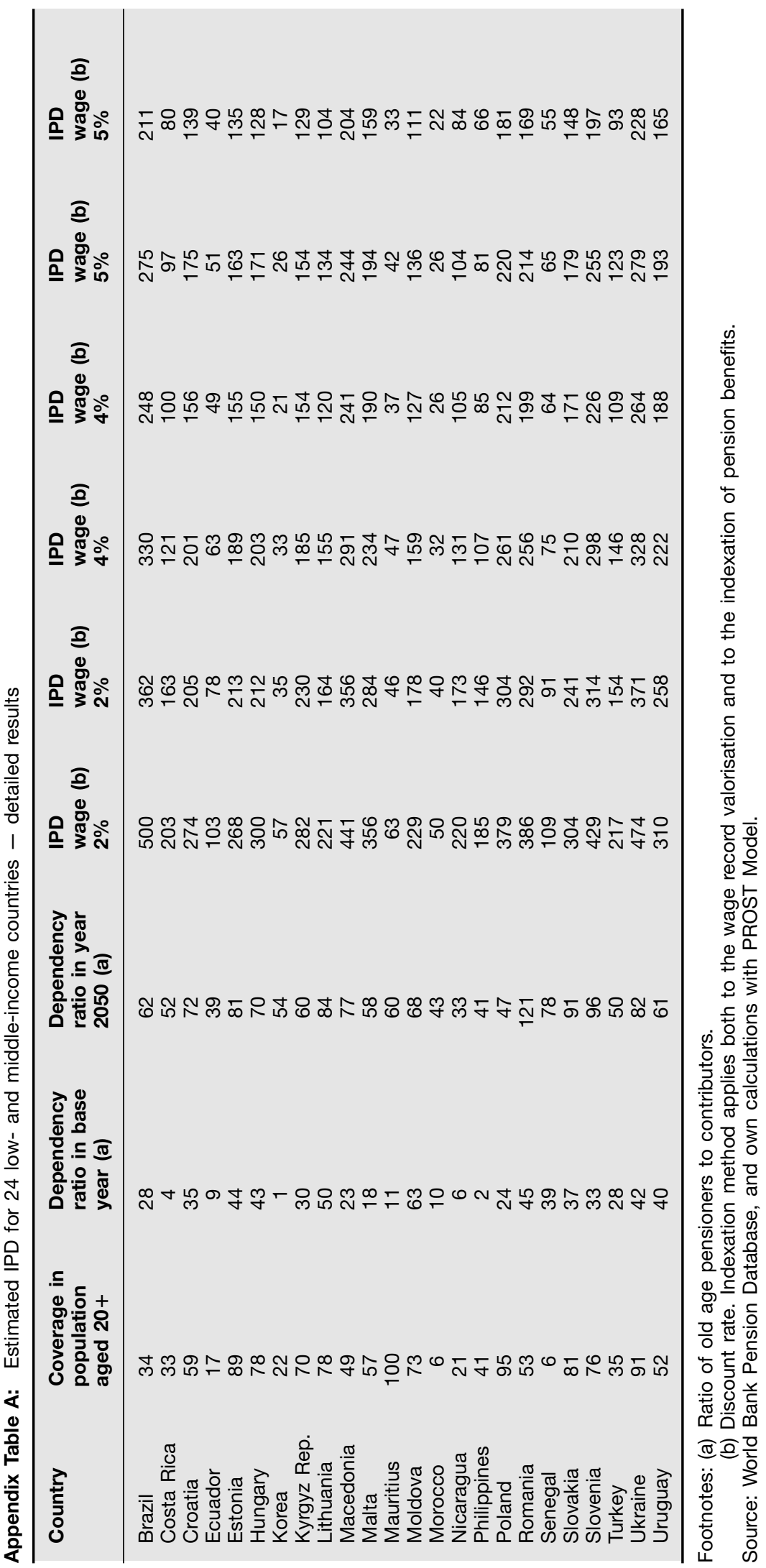

